\title{
The motivation of rice farmers toward organic rice farming in Sleman Regency
}

\author{
Nur Rahmawati ${ }^{1,}$, Kristi Juwati ${ }^{1}$, and Nor Lailatul Azilah Hamdzah ${ }^{2}$ \\ ${ }^{1}$ Agribussines Department,Universitas Muhammadiyah Yogyakarta. 55183 Yogyakarta, Indonesia. \\ ${ }^{2}$ Universiti Teknikal Malaysia Melaka, Malaysia
}

\begin{abstract}
This study aims to determine the motivation of rice farmers toward organic rice farming and the factors of their motivation in organic farming. The research was conducted in Sleman Regency as it has applied the principles of organic rice, although not completely. The sample in this study amounted to 91 farmers. This study employed descriptive analysis with scoring technique and motivation model using the ERG theory. The results uncovered that the motivation of rice farmers in Sleman Regency toward organic rice farming, especially on the needs for existence, belonged to the high category with an average score of 3.78 , the relatedness needs was included in the high category with an average score of 4.15 , and the growth needs was also in the high category with an average score of 3.43. Therefore, the motivation of rice farmers toward organic rice farming in Sleman Regency, particularly in fulfilling primary, interaction, and developing needs, was high.
\end{abstract}

\section{Introduction}

Indonesia is an agrarian country where most of the population work as farmers. Abundant natural resources are potential for agricultural development in Indonesia. It makes Indonesia a country capable of producing various types of plants, especially the staple food of carbohydrates such as rice. The increasing population can affect the demand for food needs, which will continue to increase [1]. The increase in food needs or national rice is believed by some circle, one of which is through the agricultural development movement that attempts to use natural ingredients input good for the environment and health. Organic farming productivity will increase, be healthy for the body, and be safe for the environment [2].

Organic farming is a process that can encourage soil and plants to stay healthy by cultivating the soil according to the principles of organic farming. Organic farming has become popular in Southeast Asia as part of a sustainable farming system [3]. Organic farming principles can provide benefits for both producers and consumers. Organic agriculture is approved as an agricultural system and environmentally-friendly agriculture food production system that positively impacts rural communities [4]. Consumer needs for organic agricultural products are greatly improved along with awareness of health, lifestyle, and concern for the environment [5]. The advantages of organic agricultural products are

${ }^{*}$ Corresponding author: rahma wati mf@umy.ac.id 
stilldebate, but it is believed that the production process organic farming is more environmentally friendly [6]

The application of organic agriculture, especially organic rice farming, requires a long time and process. It does not necessarily change conventional to organic farming. Barriers to conversion to organic farming include cost issues, lack of knowledge, lack of government support, fear of the future, and low production is the hardest challenge for conversion to organic farming [7]. Other challenges are negative pressure from other farmers and farm groups and lack of physical and financial capital [8]. The application of technology in organic rice farming varies between regions [9].

Initially, organic farming principle application will affect land production, such as a decrease in its function caused by the early transition from conventional to organic farming. It is due to the land transition process that gradually reduces the use of chemicals. Producing organic rice takes years because it has to go through a transition period to be completely organic.

Sleman Regency is an area that has applied the principles of organic agriculture, especially the organic rice commodity. Six districts in Sleman Regency have implemented organic farming principles, such as Pakem, Cangkringan, Berbah, Sleman, Godean, and Seyegan. Several farmer groups in the Sleman Regency have not applied the principles of organic rice farming because they are constrained by market prices that are not as expected

Although there have been efforts to implement the principles of organic farming, it is still unsustainable or takes time for farmers to transition from conventional to organic rice farming. Thus, it causes some farmers in the next growing season to switch to conventional farming as a whole. In recent years, there has been a downward trend infarmers' land and the number of certified organic rice farmers in the Nurani Sejahtera Farmers Group [10].

The sustainability of this threatened organic rice farming causes the land area and production of organic rice to decrease. However, several members of farmer groups are still consistent in applying the principles of organic farming. Therefore, it is interesting to discuss their motivation in organic rice farming.

There have been many studies on motivation, including The Motivation for Organic Grain Farming [11], Young Farmers' Motivation and Participation in Horticultural Organic Farming [12], German Winegrowers' Motives [13], Motivation of Coffee Farmers in South Tapanuli Regency [14] and The study of the motivation of farmers in Klaten, Central Java, uses Maslow's theory of needs [15]. Hence, this study analyzed the motivation of organic rice farmers with the ERG theory. This study aims to determine the motivation of organic rice farmers in Sleman Regency who are still consistent in developing organic rice farming.

\section{Research Method}

Research on the motivation of farmers in organic rice farming was carried out in Sleman Regency with consideration that several rice farmer groups in this regency have applied the principles of organic farming, although not yet purely. This research utilized purposive sampling or deliberately sampling by selecting farmer groups in six districts, comprising Bebah, Godean, Pakem, Seyegan, Cangkringan, and Sleman. The sample consisted of 91 farmers from 14 farmer groups, as displayed in Table 1.

Descriptive and motivation analyses were applied to determine the motivation of semiorganic rice farmers in Sleman Regency. The motivation analysis model utilized the ERG theory consisting of the needs for existence, relatedness, and growth, divided into high, medium, or low categories. 
Table 1. Data of farmers applying semi-organic rice farming in Sleman Regency.

\begin{tabular}{|c|l|l|c|c|}
\hline No & Farmer Group & District & $\begin{array}{c}\text { Number of } \\
\text { Members }\end{array}$ & $\begin{array}{c}\text { Number of } \\
\text { Organic Rice } \\
\text { Farmers }\end{array}$ \\
\hline 1 & Sri Rejeki & Godean & 25 & 10 \\
\hline 2 & $\begin{array}{l}\text { Ngudi } \\
\text { Makmur I }\end{array}$ & Godean & 16 & 8 \\
\hline 3 & $\begin{array}{l}\text { Ngudi } \\
\text { Makmur II }\end{array}$ & Godean & 24 & 12 \\
\hline 4 & $\begin{array}{l}\text { Manunggal } \\
\text { Karso }\end{array}$ & Godean & 47 & 8 \\
\hline 5 & Tani Makmur & Godean & 50 & 4 \\
\hline 6 & Sido Rukun & Godean & 21 & 8 \\
\hline 7 & Tani Rukun & Godean & 26 & 3 \\
\hline 9 & Rukun & Pakem & 30 & 6 \\
\hline 10 & $\begin{array}{l}\text { RukunAbadi } \\
\text { Sentosa }\end{array}$ & Pakem & 35 & 6 \\
\hline 11 & Gemilang & Cangkringan & 20 & 12 \\
\hline 12 & Setia Maju & Sleman & 20 & $\mathbf{9 1}$ \\
\hline 13 & $\begin{array}{l}\text { Mulyo } \\
\text { Makmur }\end{array}$ & Seyegan & 55 & \\
\hline 14 & Sido Rukun & Berbah & 55 & \\
\hline & & & & \\
\hline
\end{tabular}

In this study, the indicators were measured by sub-indicators with a score of 5 scales. There are strongly disagree with a score of 1 , disagree with a score of 2 , neutral with a score of 3 , agree with a score of 4 , and strongly agree with a score of 5 , as depicted in Table 2. Measurement of categories employed the following interval formula:

$$
\begin{aligned}
& \text { Interval }=\frac{\text { skor tertinggi-skor terendah }}{\sum \text { katagori }} \\
& \text { Interval }=\frac{5-1}{5}=0,8
\end{aligned}
$$

Table 2. Interpretation of determining the level of criteria for each indicator.

\begin{tabular}{|c|c|l|}
\hline No & Score & \multicolumn{1}{c|}{ Categories } \\
\hline 1 & $1.00-1.80$ & Very Low \\
\hline 2 & $1.81-2.60$ & Low \\
\hline 3 & $2.61-3.40$ & High Enough \\
\hline 4 & $3.41-4.20$ & High \\
\hline 5 & $4.21-5.00$ & Very High \\
\hline
\end{tabular}

\section{Results and Discussion}

Motivation is a set of forces or drives that cause farmers to behave in a certain way to do something they want. Their motivation to carry out organic rice farming in Sleman Regency is based on reasons, and every farmer certainly has different motivations. In this study, organic rice farmers' motivation was measured using the ERG theory analysis, consisting of the needs for existence, relatedness, and growth. 


\subsection{Existence}

The needs for existence encourage farmers to fulfill their daily needs such as clothing, food, shelter, as well as long-term needs, both security needs such as opening savings in banks, having family life insurance, feeling safe, and old age guarantee. In the motivation of existence, there are five indicators. The indicators are motivation to fulfill the family's clothing needs, food needs, family needs, children's education costs, and food security needs. The average score of each criterion on these existence indicators is in the high category with a total average of 3.87 , as demonstrated in Table 3.

Table 3. Motivation score of organic rice farmers on the needs for existence.

\begin{tabular}{|c|c|c|c|}
\hline No & Indicator & Score & Category \\
\hline \multicolumn{4}{|c|}{ Existence } \\
\hline \multirow[t]{3}{*}{1} & \multicolumn{2}{|l|}{ Motivation to fulfill the needs of the family clothing } & \\
\hline & $\begin{array}{l}\text { a. Encouraged to fulfill the family's clothing needs in } \\
\text { the form of clothing }\end{array}$ & 4.18 & High \\
\hline & $\begin{array}{l}\text { b. Encouraged to fulfill the clothing needs of children's } \\
\text { school uniforms }\end{array}$ & 3.66 & High \\
\hline \multirow[t]{3}{*}{2} & \multicolumn{2}{|l|}{ Motivation to fulfill the needs of the family food } & \\
\hline & $\begin{array}{l}\text { a. Encouraged to fulfill the food needs of family three } \\
\text { times a day }\end{array}$ & 4.38 & Very High \\
\hline & $\begin{array}{l}\text { b. Encouraged to fulfill healthy and nutritious food } \\
\text { needs }\end{array}$ & 4.33 & Very High \\
\hline \multirow[t]{3}{*}{3} & \multicolumn{2}{|l|}{ Motivation to fulfill the needs of the family house } & \\
\hline & $\begin{array}{l}\text { a. Encouraged to fulfill the needs of the family house } \\
\text { where place to live }\end{array}$ & 4.16 & High \\
\hline & $\begin{array}{l}\text { b. Encouraged to fulfill the needs of the family house by } \\
\text { completing household furniture. }\end{array}$ & 4.11 & High \\
\hline \multirow[t]{3}{*}{4} & \multicolumn{2}{|l|}{ Motivation to fulfill the needs of the children education } & \\
\hline & a. Encouraged to fulfill children's education costs & 3.82 & High \\
\hline & $\begin{array}{l}\text { b. Encouraged to fulfill support costs } \\
\text { education }\end{array}$ & 3.70 & High \\
\hline \multirow[t]{6}{*}{5} & Motivation to fulfill the needs of the security & & \\
\hline & $\begin{array}{l}\text { a. Encouraged to have savings in the bank } \\
\text { for future needs }\end{array}$ & 3.46 & High \\
\hline & $\begin{array}{l}\text { b. Encouraged to have life insurance for } \\
\text { family }\end{array}$ & 2.96 & High Enough \\
\hline & $\begin{array}{l}\text { c. The organic rice farming that I can } \\
\text { provide a sense of security and old age guarantee }\end{array}$ & 2.90 & High Enough \\
\hline & Total & 41.67 & \\
\hline & Average & 3.78 & High \\
\hline
\end{tabular}

As exhibited in Table 3, the indicator of existence needs with the highest score is motivation to fulfill family food needs because food is a source of life for humans and a primary need. Family food needs must be fulfilled to support farmers' families. In this case, 
it was the encouragement of farmers to meet the daily consumption needs of the family. Motivation to fulfill the food needs three times a day belonged to a very high category with a score of 4.38 , followed by meeting the needs of healthy and nutritious food with a score of 4.33. The results indicate that farmers have a very high motivation to fulfill the family's food needs three times a day. It was more important than the motivation to fulfill the needs of healthy and nutritious food for their families. Even though sometimes the income was sufficient, farmers had a high responsibility in meeting the family's consumption needs.

The lowest indicator of motivation in existence was that organic rice farming could provide a sense of security and guarantee for old age, including a high category with a score of 2.90. It implies that the motivation of farmers to perform organic rice farming is not only for their consumption but also to ensure environmental sustainability. It certainly provided farmers a sense of security when consuming rice from organically grown rice because most farmers preferred consuming their organic rice farming products to selling them to the market. It was a strong enough reason for farmers to continue farming organic rice because it provided a sense of security when consumed. In essence, not all farmers (45\%) agreed with it because most of them, when switching to organic farming principles, experienced a decrease in production, and the market price of organic rice was relatively low or almost the same as the price of conventional rice. Therefore, farmers believed that organic rice farming did not provide a sense of security and security in old age. Overall, the motivation of farmers to carry out farming seen from their successive existence was to meet the needs of food, clothing, housing, education, and security.

\subsection{Relatedness}

The needs for relatedness encourage farmers to interact and relate to other farmers or people other than farmers. As demonstrated in Table 4, the total motivation score on the relatedness indicators is in the high category. It indicates that farmers tend to be strong in interacting and socially related to organic farming.

Establishing relationships with agricultural extension workers have been carried out to increase the motivation of farmers in organic rice farming in Sleman Regency. Every social being needs interaction because every farmer living in a social order must interact to maintain a good relationship. As displayed in Table 4, the highest motivation score on relatedness is in the motivation to interact with other farmers by establishing good relationships with other farmers, included in the very high category, with a score of 4.29 . It means that farmers interact with other farmers to strengthen relations and increase kinship between farmers. The research on the impact of agricultural extension on nutrition management in China revealed that agricultural extension services were essential to increase farmers' knowledge with information about nutrition management [16]. Close friendships and a high level of kinship certainly positively impacted every farming activity as other farmers who got into trouble would assist other farmers. In addition, by staying in touch, farmers could actively participate in activities held by extension workers or farmer groups, with a score of 4.20. Actively participating in activities held by extension workers or farmer groups would certainly add insight and knowledge of farmers in organic farming. Hence, the farmers could be more open and convenient in applying the principles of organic farming and technology and innovations concerning organic farming information.

The lowest motivation score on the needs for relatedness of organic rice farmers, as depicted in Table 4, is to provide beneficial experiences to other farmers about organic farming, obtaining a score of 4.01 (high category). It indicates that the experiences of other farmers will provide additional information and insight for farmers in applying the principles of organic farming. However, sharing experiences with other farmers was not easy, or not all farmers were willing to conduct it. Achievement motivation, sharing 
experiences, and fear of success affected the performance of women farmers in the Seke Subak organization [17]. The heads of farmer groups and agricultural extension workers have been considered to have more knowledge and experience both theoretically and technically in applying agriculture principles. Therefore, the role of agricultural extension workers must be increased. Moreover, they should help control communication between local leaders and farmers [12].

Table 4. Motivation score of organic rice farmers on the needs for relatedness.

\begin{tabular}{|c|c|c|c|}
\hline No & Indicator & Score & Category \\
\hline \multicolumn{4}{|c|}{ Relatedness } \\
\hline \multirow[t]{3}{*}{1.} & \multicolumn{3}{|c|}{\begin{tabular}{|l|} 
Motivation to build relationships with agricultural extension workers \\
\end{tabular}} \\
\hline & $\begin{array}{l}\text { Encouraged to dig up information about } \\
\text { organic farming outside of extension activities }\end{array}$ & 4.14 & High \\
\hline & $\begin{array}{l}\text { Encouraged to continue to coordinate with } \\
\text { agricultural extension workers related to } \\
\text { farmers' problems. }\end{array}$ & 4.11 & High \\
\hline \multirow[t]{3}{*}{2} & \multicolumn{2}{|l|}{ Motivation to interact with other farmers } & \\
\hline & $\begin{array}{l}\text { Driven to be in a good relationship with other } \\
\text { farmers }\end{array}$ & 4.29 & Very High \\
\hline & $\begin{array}{l}\text { Encouraged to actively participate in } \\
\text { participating in activities held by extension } \\
\text { workers/farmer groups }\end{array}$ & 4.20 & High \\
\hline 3 & \multicolumn{2}{|l|}{ Motivation to cooperate with other farmers } & \\
\hline & $\begin{array}{l}\text { Encouraged to help other farmers if they have } \\
\text { difficulty in organic farming }\end{array}$ & 4.15 & High \\
\hline & $\begin{array}{l}\text { Encouraged to provide useful information to } \\
\text { other farmers }\end{array}$ & 4.13 & High \\
\hline & $\begin{array}{l}\text { Encouraged to obtain new experiences from } \\
\text { other farmers }\end{array}$ & 4.11 & High \\
\hline \multirow[t]{5}{*}{4} & \multicolumn{2}{|c|}{ Motivation to share experiences with other farmers } & \\
\hline & $\begin{array}{l}\text { Encouraged to provide valuable experiences to } \\
\text { other farmers about organic farming }\end{array}$ & 4.01 & High \\
\hline & $\begin{array}{l}\text { Encouraged to learn from the experiences of } \\
\text { other farmers as additional knowledge }\end{array}$ & 4.13 & High \\
\hline & Total & 37.37 & \\
\hline & Average & 4.15 & High \\
\hline
\end{tabular}

\subsection{Growth}

The needs for growth encourage farmers to develop for a better future, such as evolve a way of thinking and self-potential in the hope that it can be beneficial for themselves, their families, and others. As presented in Table 5, the motivation of organic rice farmers seen from the growth needs belongs to the high category, with an average score of 3.43 . It signifies that farmers have a high motivation to develop organic rice farming in terms of creativity and productivity both within themselves and the surrounding environment. Hence, they can later apply the principles of organic farming, maintain the ecosystem using organic materials and maintain health by consuming healthy food from organic farming.

The motivation of organic rice farmers to increase knowledge about organic farming obtained the highest score. Organic rice farmers actively participated in training and counseling, as displayed by the motivation score being in the high category with a score of 
4.02. The training and counseling held became new material for farmers and could ease organic farming principles application. However, since last year, training and counseling have been rarely conducted due to the COVID-19 pandemic. Thus, the counseling and training, as well as farmer group meetings, were no longer carried out. Although the meeting was held, the atmosphere was not conducive, and not all members of the farmer group attended the meeting, resulting in a delay in the information to be conveyed.

In addition to participating in training and counseling, organic rice farmers could increase their knowledge by seeking information about organic farming with experts, obtaining a score of 4.01. It implies that farmers are motivated to know more or try to find information from experts, be it group leaders or agricultural extension workers applying the principles of organic farming.

Table 5. Motivation score of organic rice farmers on the needs for growth

\begin{tabular}{|c|c|c|c|}
\hline No & Indicator & Score & Category \\
\hline \multicolumn{4}{|c|}{ Growth } \\
\hline \multirow[t]{4}{*}{1} & \multicolumn{3}{|c|}{ Motivation to apply the use of modern equipment that supports farming } \\
\hline & Encouraged to use modern farming tools & 3.60 & High \\
\hline & $\begin{array}{l}\text { Encouraged to use the internet to find information } \\
\text { about organic farming }\end{array}$ & 3.27 & High Enough \\
\hline & $\begin{array}{l}\text { Encouraged to implement marketing of farming } \\
\text { products through marketplaces (Shopee, } \\
\text { Tokopedia, etc.) }\end{array}$ & 2.99 & High Enough \\
\hline \multirow[t]{3}{*}{2} & \multicolumn{3}{|c|}{ Motivation to increase knowledge about organic farming } \\
\hline & $\begin{array}{l}\text { Encouraged to take part in organic farming } \\
\text { counseling and training }\end{array}$ & 4.02 & High \\
\hline & $\begin{array}{l}\text { Encouraged to seek information about organic } \\
\text { farming with the experts }\end{array}$ & 4.01 & High \\
\hline \multirow[t]{4}{*}{3} & \multicolumn{3}{|l|}{ Motivation to buy tertiary goods for the family } \\
\hline & Encouraged to buy electronic devices & 3.16 & High Enough \\
\hline & Driven to buy jewelry & 2.91 & High Enough \\
\hline & Driven to buy a vehicle & 2.91 & High Enough \\
\hline \multirow[t]{3}{*}{4} & \multicolumn{3}{|l|}{ Motivation to be appreciated and respected by others } \\
\hline & $\begin{array}{l}\text { Encouraged to play an active role in the application } \\
\text { of organic farming }\end{array}$ & 3.96 & High \\
\hline & Encouraged to take part in group decisions & 3.93 & High \\
\hline \multirow[t]{5}{*}{5} & \multicolumn{3}{|l|}{ Motivation to have a business from organic farming } \\
\hline & $\begin{array}{l}\text { Encouraged to open a business from organic } \\
\text { agricultural products }\end{array}$ & 3.20 & High Enough \\
\hline & $\begin{array}{l}\text { Encouraged to develop existing businesses from } \\
\text { organic agricultural products }\end{array}$ & 3.19 & High Enough \\
\hline & Total & 41.16 & \\
\hline & Average & 3.43 & High \\
\hline
\end{tabular}

The lowest motivation score for organic rice farmers on growth needs was motivation to buy tertiary goods for the family, such as purchasing vehicles and jewelry, with a score of 2.91. The category score for the purchase of transport and jewelry was high enough, but purchasing tertiary goods was not a priority because many organic rice farmers were still unmotivated to buy these goods because they were not considered a priority in fulfilling their daily needs. Unlike the research results of [11], discovering that many organic grain producers had more than a single motivation and the farmers were more likely to be motivated by lifestyle goals. 
It was interesting to know that the motivation of organic farmers in Sleman Regency, seen from the needs for growth, was the motivation to have a business from organic agricultural products. They were encouraged to open and develop their work from organic agricultural products. The study results stated that farmers had hope in the future to be able to open businesses from organic farming, although it was still a desire.

In this study, rice farmers' motivation was measured using the ERG theory with the variables of the needs for existence, relatedness, and growth.

Table 6. Motivation score with the ERG theory.

\begin{tabular}{|l|c|c|}
\hline \multicolumn{1}{|c|}{ ERG Motivation } & Score & Category \\
\hline Existence & 3.78 & High \\
\hline Relatedness & 4.15 & High \\
\hline Growth & 3.14 & High \\
\hline Motivation Average & 3.69 & High \\
\hline
\end{tabular}

Table 6 reveals that organic rice farmers in Sleman Regency have high motivation, with a score of 3.69 , to continue to develop organic rice farming even though many of them switch to conventional rice farming. The motivation for organic barley farming in Central Java was high [5]. The level of motivation of farmers in Arabica coffee farming in South Tapanuli Regency was also in the high category (51.66\%) [14].

Based on the ERG theory, the needs for relatedness obtained the highest score of 4.15 because, to develop organic rice farming, farmers required frequent interaction with fellow farmers. Besides being able to establish friendships, farmers could share experiences and learned together with agricultural extension workers. The needs for existence got a score of 3.78 , belonging to the high category. One of the goals of organic rice farming is to motivate farmers to fulfill their primary needs such as clothing, food, housing, and a sense of security. The motivation of farmers to farm organic rice to meet the needs of growth received a score of 3.43 and was included in the high category. For organic farmers, efforts to increase self-capacity, including self-actualization in the development of organic agriculture, were not substantial. They felt enough if they could produce organic rice and increase family income to meet their needs. Most of the total organic rice farmers $(54 \%)$ in Central Java stated that the motivation for organic rice farming was to obtain quality organic rice products and high income [5].

\section{Conclusions}

Organic rice farmers in Sleman Regency had high motivation, with a score of 3.69, to continue to develop organic rice farming even though many of them have switched to conventional rice farming. Based on the ERG theory, the needs for relatedness obtained the highest score of 4.1 , being in the high category. The needs for existence gained a score of 3.78 , belonging to the high category. Meanwhile, the motivation of farmers to farm organic rice to meet the needs for growth had a score of 3.43, with the high category.

The role of extension workers was crucial in increasing the motivation of farmers in organic rice farming, such as training on innovations in organic rice development.

The strengthening of farmer groups and their members is expected to establish good coordination and communication so that they can collaborate well in applying the principles of organic farming. Increasing enthusiasm in farming with good communication aims to keep farmers consistent in carrying out organic rice farming even though it is not purely organic. In addition, production results can be further improved to be adequately marketed to increase farmers' income. 


\section{Reference}

1. J. K. Hasugian, Y. Damayanti, and S. Nainggolan, J. Ilm. Sosio-Ekonomika Bisnis 19, 8 (2016).

2. J. Sari, I. Nurmayasari, and H. Yanfika, J. Ilmu-Ilmu Agribisnis 3, 432 (2015).

3. S. Chouichom and M. Yamao, J. Org. Syst. 5, 25 (2010).

4. S. Kennvidy, IJERD - Int. J. Environ. Rural Dev. 2 (2011).

5. T. Dalmiyatun, B. T. Eddy, W. Sumekar, and D. Mardiningsih, IOP Conf. Ser. Earth Environ. Sci. 102, (2018).

6. W. Widodo, D. Rina Kamardiani, and L. Rahayu, Agrar. J. Agribus. Rural Dev. Res. 2, 134 (2016).

7. A. Asadollahpour, M. O. Najafabadi, and S. J. Hosseini, J Sci Int 26, 1665 (2014).

8. H. Veisi, M. S. Carolan, and A. Alipour, Int. J. Agric. Sustain. 15, 303 (2017).

9. Y. K. Lestari and A. T. Suryana, Sustain. Org. Rice Farming Indones. 55 (2013).

10. T. Karyani, F. Arifin, H. Hapsari, and E. Supriyadi, IOP Conf. Ser. Earth Environ. Sci. 306, (2019).

11. H. H. Peterson, A. Barkley, A. Chacón-Cascante, and T. L. Kastens, J. Agric. Appl. Econ. 44, 137 (2012).

12. D. F. Widhiningsih, Int. J. Soc. Ecol. Sustain. Dev. 11, 45 (2020).

13. L. Siepmann and K. A. Nicholas, Sustain. 10, 1 (2018).

14. Y. Yuliana, T. Ekowati, and M. Handayani, Agrar. J. Agribus. Rural Dev. Res. 3, (2017).

15. Indardi and R. Budi Nugroho, in E3S Web Conf., edited by Juwaidah, P. Saiyut, M. M. Tjale, and Z. Rozaki (2021), p. 01026.

16. D. Pan, Sustain. 6, 6644 (2014).

17. H. Hardin, L. O. M. Mustari, and W. Sari, Int. J. Manag. Prog. 1, 10 (2019). 